\title{
Gender Differences in Time in Child Care During Unemployment
}

\author{
Margaret Gough Courtney ${ }^{1}$ \\ University of La Verne, La Verne, CA
}

Running Head: Gender, Unemployment, and Time in Child Care

Keywords: child care, unemployment, work and family, gender and family, household labor, family demography

${ }^{1}$ Mail correspondence may be directed to Dr. Margaret Gough Courtney, Department of Sociology \& Anthropology, University of La Verne, Hoover Building 118A, La Verne, CA 91750. Email mgough@laverne.edu; phone 909-448-1581. The author acknowledges support from a National Science Foundation (NSF)-American Sociological Association Postdoctoral Fellowship. NSF had no involvement in the analysis or interpretation of the data presented in this paper. Alexandra Killewald and Joseph Cabrera provided helpful comments on previous versions of this article. 


\section{Gender Differences in Time in Child Care During Unemployment}

\section{Abstract \\ Objectives}

There is great interest in the relationship between paid and unpaid labor time. Yet, in the United States most studies have focused on the housework component of unpaid labor. Limited research has examined how parental employment status relates to child care time. This study examines how unemployment is related to time in multiple types of child care and how this relationship varies by gender.

\section{Methods}

I use data from the 2003-2013 American Time Use Surveys to study cohabiting and married parents ages $18-65(N=44,198)$. I predict time spent in total child care, routine child care, and educational/recreational child care by parental unemployment status using ordinary least squares and seemingly unrelated regression models, and examine differences between weekday and weekend time use.

\section{Results}

Consistent with time-based theories, I find unemployed parents spend more time in child care than employed parents, but patterns vary by gender: unemployed mothers and fathers spend more time in child care on weekdays, but unemployed fathers spent less time in child care on weekends.

\section{Conclusions}

Results suggest similarities and differences between the unemployment-child care time relationship and the relationship of unemployment with other types of unpaid labor such as housework. 


\section{Gender Differences in Time in Child Care During Unemployment}

Although an extensive literature has examined engagement in paid labor and how it relates to the division of unpaid labor (housework and care work) in families (e.g., Bittman et al. 2003, Gough and Killewald 2011, Hochschild and Machung 1989, Raley et al. 2012; Roeters et al. 2009), less attention has been paid to unemployment as it relates to time in child care. Yet, child care is a common, labor-intensive form of unpaid labor that is closely tied to parents' labor force participation, especially for mothers (Hochschild and Machung 1989).

This study contributes to the literature by using data on involuntary unemployment to better understand how engagement in paid labor, or the lack thereof, is associated with the gendered allocation of time to unpaid labor, specifically child care. Using the American Time Use Survey (ATUS) I test household labor theories in the child care context, comparing unemployed (and looking for work) and employed mothers on the one hand and unemployed (and looking for work) and employed fathers on the other. I pay close attention to gender differences because unpaid labor is strongly gendered—normative for women but not men (West and Zimmerman 1987) — and to differences in the types of child care activities-routine versus interactive (Roeters et al. 2009).

Understanding time spent in child care is important when thinking about how paid labor may affect the division of unpaid labor in households. Because child care is costly (Blau 2001) and more commonly outsourced than other household labor (Sullivan and Gershuny 2013) one might expect to see large changes in child care time during unemployment because of reduced income, with the excess burden placed on the unemployed parent. This could have implications for the balance of power in households and the unemployed parent's ability to achieve reemployment. Studying time in child care may also provide additional insights into the gender 
division of labor in households. For example, some theories suggest that partners seek to bargain out of housework because it is undesirable (Bittman et al. 2003, Brines 1994), but there is less evidence that this is true for child care (Raley et al. 2012). Rather, parents often report that they enjoy spending time with children, especially time in educational or play activities (Krueger et al. 2009, Robinson and Godbey 1999). And, unlike the negative educational gradient for housework, there is a positive gradient for child care: college-educated parents spend more time in child care than less educated parents (Guryan et al. 2008), possibly because they see parenting as an investment in their child's future (Connelly and Kimmel 2010). Thus, while the division of child care in a household could have similar attributes to the division of other types of unpaid labor, there may also be something fundamentally different about dividing child care time. Although the data do not allow me to study allocations of time at the dyad level, I provide individual-level evidence of how unemployed parents engage in child care, and relate this to relevant theories.

\section{Background}

\section{Theory}

Three general theoretical perspectives govern much of the research on the division of unpaid labor, having been developed most extensively by housework researchers and extended in various ways to the child care literature (Raley et al. 2012, Roeters et al. 2009). These perspectives are described in greater detail elsewhere (e.g., Bianchi et al. 2000), so I provide only a brief overview of each to motivate the hypotheses. The time and resource theories are primarily conceived as dyadic theories, but here, as in other child care studies using ATUS data (e.g., Chesley and Flood 2017, Craig and Mullan 2010), only the individual implications of the theories are tested because the ATUS collects time-use data from only one parent in the 
household.

In the housework literature, time availability theory posits that the partner with more time available for housework will contribute more to family responsibilities, such as housework and child care, than the partner with less time available (Bianchi et al. 2000, England and Farkas 1986). For example, in a household in which the wife works part time and the husband works full time, the theory predicts the wife will do much more household work than the husband. Similarly, the demand/response capacity approach in the child care literature (Brayfield 1995, Coverman 1985), assumes parents can substitute for one another in child care based on demands they face in the labor market (Roeters et al. 2009:1195). Employed parents may be limited in their ability to be involved in child care because of time scarcity (Bianchi 2000), but unemployed parents do not spend time in paid labor, so they should theoretically have more time for child care, even if they are spending some time searching for a job. Furthermore, given typical work patterns, unemployed parents often experience a significant reduction in weekday time constraints, so their time in child care may be more responsive on weekdays than on weekends. Thus, for individual parents, and regardless of their partner's involvement in child care, these time-based theories lead me to hypothesize that:

Hypothesis 1A (HIA): Unemployed parents will spend more time in child care than employed parents.

Hypothesis $1 B(H 1 B)$ : There will be a larger gap in child care time between unemployed and employed parents on weekdays, when employed parents typically have greater time constraints, than weekends.

Resource theory is the second common theoretical perspective used to explain the division of unpaid labor. In the housework context, relative resources or bargaining theory states 
that the partner with relatively greater resources (typically operationalized as income) has more power to bargain out of housework, and will therefore do less, than the partner with fewer resources (Bittman et al. 2003, Brines 1994). Autonomy theory states that individuals, usually women, use their earnings to either buy substitutes for their unpaid labor time (e.g., prepared meals) (Gupta 2007) or to forego housework (Gupta 2006, 2007, Killewald and Gough 2010).

It is difficult to apply relative resource theory at the individual level because it is foundationally about bargaining. Additionally, extending resource theories to child care is not entirely straightforward (Raley et al. 2012). Whereas housework is considered by most to be an undesirable activity to be bargained away or outsourced, the literature suggests that parents like spending time with their children (e.g., Robinson and Godbey 1999). Thus, it is not clear that parents would want to use their resources to bargain out of child care. On the other hand, there are ways in which having relatively greater resources could matter. Not all child care is created equal; routine child care, such as feeding and bathing children, is considered to be more mundane and less enjoyable than child care related to play (Sayer et al. 2004). Raley and colleagues (2012) also noted that parents might find certain child-related tasks like transportation onerous. For these reasons, in the event of unemployment, a still-employed partner may desire to shift these routine or onerous child care tasks to the unemployed parent, using a bargaining strategy. While I cannot test whether such a "shift" is happening, evidence of greater time in routine child care among the unemployed compared to employed parents with similar characteristics may provide indirect evidence for this theory.

Perhaps more than relative resources theory, autonomy theory can also be extended to child care; parents, particularly mothers, may use their individual earnings to purchase substitutes for their own time in child care, such as services at a day care center. Although 
parents reportedly enjoy child care, it remains the most-outsourced household task (Sullivan and Gershuny 2013), likely because it facilitates dual-earning. In the event of unemployment, individual resources may be constrained, and parents may do more child care themselves, outsourcing less.

As described above, bargaining theory can be tested indirectly by looking at time in different types of child care_-routine versus educational/recreational. But without data on outsourcing it is not possible to conclusively distinguish between autonomy and time-based mechanisms because unemployment affects both time and individual financial resources. Because of the conflicting theoretical predictions of resource theories in the child care context, and the difficulty of testing bargaining without data on partner's time use, I test the resource theories indirectly and hypothesize that:

Hypothesis 2 (H2): The gaps in child care time between unemployed and employed parents will be larger for routine child care tasks than for educational or recreational child care tasks because routine tasks may be less desirable.

Both the time- and resource-based theories are conceived of as gender neutral because they assume that, net of economic characteristics, men and women are equally likely to use their time or resources rationally; this ignores the fact that time in paid and unpaid labor is gendered. Full-time work in paid labor is normative for men (West and Zimmerman 1987), and increasingly for women. But, time in unpaid labor is normative for women and less so for men (Berk 1985, West and Zimmerman 1987). In recent decades a norm of "intensive mothering" has developed for women, which reinforces traditional gender norms. The idea behind intensive mothering is that women are responsible for their children's physical, emotional, and developmental needs and should be extremely devoted to their children (Hays 1998). Some 
similar changes in norms have occurred for fathers. Although traditionally time in housework and child care was normative for women but not men, in recent decades the role of the father has changed in significant ways, such as through the development of a new ideal father norm. This norm suggests that fathers should provide daily physical and emotional support to children (Goldscheider and Waite 1991) and that men should be more involved in the home (e.g., Coltrane 1996). Many men seem to subscribe to this ideal (Gerson 1993, 2010) whether or not they actually implement it.

These gender norms and gender roles relate to the third theoretical perspective to inform this study — West and Zimmerman's (1987) "doing gender" theory. Unlike the time and relative resource theories, doing gender theory is not necessarily built upon the premise of dyadic decision making. As applied to housework, the theory states that housework is a venue in which men and women perform their gender roles, with men eschewing housework and women embracing housework. Although this might also be true for child care, the potentially competing norm of the new father role, and the fact that both fathers and mothers tend to enjoy time with their children, means the implications of the theory are not immediately clear for child care. Past research has found that mothers' time in child care regularly exceeds fathers' time (e.g., Raley et al. 2012), which could be consistent with doing gender. If women and men also do gender through child care, perhaps to a lesser extent than for housework, and routine child care is more similar to housework (normative for women but not men) than educational/recreational child care because it is less desirable and less optional (Sayer et al. 2004), I hypothesize that: Hypothesis $3 A(H 3 A)$ : The gap in child care time between unemployed and employed mothers will be larger than the gap between unemployed and employed fathers because unemployment reduces the time constraints on doing gender through child care. 
Hypothesis $3 B(H 3 B)$ : The gap in child care time between unemployed and employed fathers will be smaller for routine child care activities than the gap for educational or recreational child care activities. Note that this hypothesis is the opposite of Hypothesis

2.

Hypothesis $3 C$ (H3C): The gap in child care time between unemployed and employed mothers will be larger for routine child care activities than the gap for educational or recreational child care activities.

\section{Past Research}

A few studies have examined the relationship between unemployment and housework time, and other studies have explored changes in fathers' involvement in child care and parents' time in different child care tasks. Studies of unemployment and housework have found that unemployed individuals spend more time in housework than employed individuals (Burda and Hamermesh 2010, Ström 2002) or that periods of unemployment are associated with greater time spent in housework compared to periods of employment (Gough and Killewald 2011, Shamir 1986). The studies provide support for the time- and resource-based theories, and one study (Gough and Killewald 2011) found support for doing gender. Using fixed-effects models, the authors demonstrated that both men and women increased time in housework during periods of unemployment, but the magnitude of the women's increase was about twice the magnitude of the men's increase. If housework and child care time have similar determinants one would expect to find results similar to those of previous housework studies.

Studies of fathers' involvement in child care have examined several facets of fathering related to labor force participation. In the 1990s, Casper (1996) found that fathers' increased involvement as primary caregivers appeared to be related to the availability of jobs and the 
economy overall. A higher percentage of children were being cared for by their fathers, and a lower percentage was attending day care centers, when unemployment and part-time employment rates were high for men during the recession of the late 1980s and early 1990s (Casper 1996).

Recent studies have shown that the ideal father norm is not being realized to the extent previously imagined, but fathers do seem to be more involved with child care than in the past, particularly on weekends. Researchers presume this to be a result of weekend involvement conflicting less with fathers' paid labor than involvement in child care during the week (Hook and Wolfe 2012, Yeung et al. 2001). If this is true, we should expect to see similar behavior from working mothers, and, as hypothesized earlier, a greater discrepancy in child care time between employed and unemployed parents on weekdays compared to weekends.

Finally, other researchers have examined fathers' and mothers' time in routine and interactive child care tasks, or how mothers' resources affect fathers' involvement in child care. Using data from the Netherlands, Roeters and colleagues (2009) found that mothers' time in child care was largely unaffected by own or spouse work demands, but fathers' participation in routine child care was more reactive to such demands. They argued that this was consistent with the notion that fathers prefer interactive activities and focus more child care time on play than routine care. Bittman and colleagues (2004) also found evidence that fathers' time in routine child care was significantly related to their spouses' market work hours, though this was not the case for interactive activities. The more time their spouses dedicated to paid labor, the more time fathers spent in routine child care. Fathers also seem more likely to participate in physical care of children when mothers have higher relative earnings (Raley et al. 2012). Thus, contrary to doing gender, there may be larger differences in time for routine tasks than for educational/recreational 
activities during a father's unemployment, a finding that would be in conflict with H3B but would support H2. I test how a partner's work hours might influence time in child care in a supplementary analysis.

\section{Method}

Data come from the 2003-2013 waves of the ATUS. The ATUS is a nationally representative time diary study conducted by the U.S. Bureau of Labor Statistics and the Census Bureau. The detailed time diary data are well suited for this study and allow me to examine time in child care overall and broken out by types of activities — routine and educational/recreational (Roeters et al. 2009 refer to the latter as "interactive"). The ATUS sample is a subsample of individuals selected from households that completed the final month of Current Population Survey (CPS) interviews. Respondents are interviewed once about their time use on the previous day; some demographic and other data are also collected. Data were extracted from ATUS-X (Hofferth et al. 2013), which is an IPUMS Time Use project.

The sample includes men and women ages 18 to 65 who are cohabiting or married, not disabled or retired at the last CPS interview, and with at least one own child under age 18 living in the household. To better reflect modern family forms, I estimate models using a combined sample of cohabiting and married parents. Results limited to married parents are very similar to those including cohabiting parents. I refer to all spouses and cohabiting partners as "partners".

I estimate models of the overall association between unemployment and time in child care for men and women separately since the analysis hinges on comparing unemployed and employed mothers along with comparing unemployed and employed fathers. In sensitivity

analyses, I test for statistically significant variation in the outcomes by subgroup, including whether results differ depending on the age of the youngest child. I also estimate supplementary 
models combining (involuntarily) unemployed and (voluntarily) out of the labor force (OOLF) fathers, some of who may be discouraged workers. Finally, to assess robustness related to partner labor force participation, I estimate models including the usual work hours of the partner.

\section{Dependent Variables}

There are three dependent variables: 1) total time in child care; 2) time in routine child care; and

3) time in educational/recreational child care. A list of the specific time-use measures used to create these variables is provided in Appendix A. Total time in child care includes a spectrum of tasks, such as physical care for children, playing with children, and so forth. It is the sum of time in all routine and educational/recreational child care tasks. Routine child care includes tasks such as physical care of children and transporting children. Educational/recreational child care includes education-related and play activities. Values of the dependent variables are top coded at the $99^{\text {th }}$ percentile and refer to only one parent in the household.

\section{Independent Variable}

The key independent variable is own unemployment at the time of the ATUS interview. The variable is binary, taking a value of 1 if the respondent reports being unemployed and looking for work and 0 otherwise. This is the same independent variable used in past research on time use during unemployment.

\section{Control Variables}

I control for two additional labor-related variables. First, I include an indicator variable for being OOLF at the time of the ATUS interview. These parents are voluntarily not working or are not searching for work. Second, to keep the household as the focus, even though partner variables are limited, I include an indicator variable for whether the partner was working at the time of the ATUS interview. Unfortunately, I cannot specifically assess partner unemployment because in 
the ATUS the unemployed and OOLF partners are combined into one category. Although previous studies have used information from the last CPS interview (e.g., Raley et al. 2012) for partner resource and employment information, I am concerned about changes occurring between the last CPS interview and the ATUS interview, especially in later years of the survey (post2008) during the Great Recession and subsequent slow recovery. As such, I rely on the data available at the time of the ATUS interview.

I also control for demographic characteristics that could be correlated with both unemployment and child care time, such as number of children, age, education, and race/ethnicity. Since everyone in the sample has at least one child I control for the number of children in the household using dummy variables to indicate the presence of two, and three or more children because the number of children is related to the amount of child care that must be completed. I also control for the age of the youngest child because as children age they take more responsibility for their own care, reducing demands on parents. I control for the respondent's age, education, and race/ethnicity. Education is a categorical variable with possible values of less than high school (includes GED), high school diploma, some college, and college degree. Race/ethnicity is a categorical variable with possible values of non-Hispanic $(\mathrm{NH})$ white, $\mathrm{NH}$ black, Hispanic, NH American Indian or Alaskan Native, NH Asian or Native Hawaiian or Other Pacific Islander, and NH multiracial. I also control for metro status (i.e., living in a metropolitan area), region, and annual state-level unemployment rate because poor local labor market conditions may affect decisions about time in household labor (Burda and Hamermesh 2010). In preliminary models I controlled for income using the categorical measure available from the last CPS interview; results were nearly identical so I use the more parsimonious model without income for all analyses presented. 


\section{Missing Data}

I drop observations with poor data quality, as indicated by BLS coding (494 observations) - the BLS flags these observations as unsuitable_-and observations with missing partner's employment status at the time of the ATUS interview (92 observations). I use missing flags for missing values on the only two covariates with missing data-metro status and age of the youngest child - with no more than 2.2 percent missing for either variable. My final analytic sample includes 44,198 respondents.

Analysis

In Model 1, I estimate the unadjusted association between unemployment and child care time. This provides initial evidence for H1A that unemployed parents will spend more time in child care than employed parents. In Model 2, I include all control variables plus a control for whether the time diary observation refers to a weekend as opposed to a weekday. This provides evidence for all of the hypotheses except for H1B, which states that the gaps in child care time between unemployed and employed parents will be larger for weekdays than for weekends. To test this hypothesis, I include an interaction between unemployment status and weekend diary in Model 3. The omitted category for Model 3 is employed with a weekday diary with three comparisons: unemployed with a weekday diary, employed with a weekend diary, and unemployed with a weekend diary. Models are weighted using the sample weights and replicate weights provided in the ATUS and are estimated using svy commands in Stata 13. Because I do not have longitudinal data to estimate models of transitions into and out of unemployment, I estimate ordinary least squares (OLS) models. I use seemingly unrelated regression (SUR) and adjusted Wald tests to assess whether differences in coefficients across models were statistically significant. 


\section{Results}

Descriptive statistics are shown in Table 1. The first three columns show statistics for fathers who are employed, unemployed, and OOLF. The next three columns show comparable statistics for mothers. There is considerable variation in child care time in the sample, as indicated in the ranges shown in the final column. On average, unemployed parents appear to spend more time in child care than employed parents but not necessarily as much time in child care as parents who are OOLF.

[Table 1 about here.]

\section{Hypothesis Testing}

Hypotheses $1 A$ and $1 B$

H1A states that unemployed parents will spend more time in child care than employed parents. The results of models testing this hypothesis are shown in Table 2, Model 2 (full results for Models 2 and 3 are available in Appendix Tables 2-4). Panel 1 of Table 2 reports the results for total time in child care; Panel 2 reports the results for routine child care; and Panel 3 reports the results for educational/recreational child care. On average, unemployed fathers spend about 35 more minutes per day in total time in child care; 22 more minutes per day in routine child care; and 12 more minutes per day in educational/recreational child care compared to employed fathers. Thus, for fathers the results support H1A.

\section{[Table 2 about here]}

Results for mothers indicate similar patterns. On average, unemployed mothers spend about 36 more minutes per day in total time in child care; 16 more minutes per day in routine child care; and 20 more minutes per day in educational/recreational child care compared to employed mothers. The results for mothers also support H1A. Overall, for both mothers and fathers, at the individual level there is initial evidence supporting the time-based theories. 
H1B states that the gaps in child care time between employed and unemployed parents will be larger for weekdays than for weekends. Results of models testing this hypothesis are shown in Table 2, Model 3. The omitted category is an employed parent with a weekday diary. Thus, to identify the gap between unemployed and employed parents on weekdays one can simply examine the magnitude of the coefficient on Unemployed — weekday diary. For weekends the gap can be calculated by subtracting the coefficient for Employed—weekend diary from the coefficient for Unemployed — weekend diary.

For fathers, the coefficient on Unemployed — weekday diary indicates that unemployed fathers spend an average of 46 more minutes per weekday in child care than employed fathers. By contrast, unemployed fathers spend 46 fewer minutes per day in child care on weekends than employed fathers (-38.70-7.70 from Table 2, Model 3). These differences are statistically significant (unadjusted Wald test: $\chi^{2}=55.42, \mathrm{p}<.001$ ). Overall, the results for fathers do not support H1B because the gaps for weekdays and weekends roughly cancel each other out, rather than the weekday gap being larger.

The results for mothers differ from those of fathers. Compared to employed mothers with weekday diaries, the Unemployed — weekday diary coefficient in Model 3 indicates that unemployed mothers spend about 37 more minutes per weekday on child care. The gap for weekend time, calculated by subtracting the coefficient for Employed—weekend diary (-25.11) from the coefficient for Unemployed—weekend diary (-4.84; not significantly different from employed, weekday diary), is about 20 minutes, but the difference in the gaps between unemployed and employed mothers for weekdays versus weekends is not statistically significant (unadjusted Wald test: $\chi^{2}=1.53, \mathrm{p}=0.22$ ). Thus, the results do not support H1B.

Hypotheses 2, 3B, and 3C 
H2 states that the gaps in child care time between employed and unemployed parents will be larger for routine child care than for educational/recreational child care activities, and H3B and $\mathrm{H} 3 \mathrm{C}$ consider possible differences in these patterns by gender. The latter hypotheses state that the gaps for fathers will be smaller for routine child care versus educational/recreational child care (H3B), which is the opposite of $\mathrm{H} 2$, whereas for mothers they will be larger (H3C). SUR and adjusted Wald tests are used with Model 2 to assess support for these hypotheses. All gaps refer to time differences between unemployed and employed parents.

Unemployed parents spend more time in routine and educational/recreational child care than employed parents across the models. Testing for differences by type of care results in mixed findings. For fathers, the gap for routine child care is substantively larger than the gap for educational/recreational child care (22 minutes vs. 12 minutes; see coefficients in Table 2), and statistically significant $(\mathrm{F}=5.80, \mathrm{p}=0.02)$. Thus, $\mathrm{H} 2$ is supported but not H3B. For mothers, the gaps are substantively closer than for fathers (16 minutes in routine care vs. 20 minutes in educational/recreational care; see coefficients in Table 2), and this 4-minute difference is not statistically significant $(\mathrm{F}=0.88, \mathrm{p}=0.35)$. Thus, for mothers, neither $\mathrm{H} 2$ nor $\mathrm{H} 3 \mathrm{C}$ are supported.

\section{Hypothesis $3 A$}

Finally, I hypothesized that the gaps in child care time between unemployed and employed mothers would be larger than the gaps between unemployed and employed fathers. Using SUR and adjusted Wald tests to compare the coefficients in Table 2, Model 2, I find minimal support for this hypothesis. For total child care time the difference (35.55-34.72 $=0.83$ minutes) is very small, and the Wald test has an F-statistic of $0.02(\mathrm{p}=.90)$. For routine child care the gap between unemployed and employed fathers (21.7 minutes) appears larger than the gap between unemployed and employed mothers (16 minutes), but this difference is not statistically significant $(\mathrm{F}=1.64, \mathrm{p}=0.20)$. For educational/recreational child care the gap between 
unemployed and employed mothers (20 minutes) is significantly larger than the gap between unemployed and employed fathers (12 minutes) $(\mathrm{F}=4.05, \mathrm{p}=.04)$. Thus, $\mathrm{H} 3 \mathrm{~A}$ is very minimally supported for educational/recreational child care only.

\section{Sensitivity Analyses}

I conduct four types of sensitivity analyses as previewed in the methods section. First, I assess whether the results differ by age of child, comparing parents of children under the age of 5 with parents of children ages 5 and older because children under the age of 5 are less likely to be in school and more likely to require considerable hands-on parental care. Results for Models 2 and 3 including an interaction with child age are shown in Table 3.

[Table 3 about here.]

Results in Table 3, Model 2 indicate that unemployed fathers spend more time in child care compared to employed fathers regardless of child age, with the exception of educational/recreational child care, for which they do not significantly differ if they have children under the age of 5. Results for Model 3 indicate that the prior patterns of unemployed fathers spending more time in child care on weekdays and less on weekends holds for fathers of children under the age of 5; unemployed fathers with children age 5 or older do more child care on weekdays but do not do less child care on weekends. This is true for total child care and routine child care. For educational/recreational child care, unemployed fathers with children age 5 or older spend more time in care on weekdays only. Results for mothers indicate that unemployed mothers spend significantly more time in total child care when children are age 5 or older, compared to employed mothers, but there are no differences among mothers of small children. This is also true for routine child care and educational/recreational child care. Results for Model 3 for mothers indicate that unemployed mothers spend more time in child care on 
weekdays when the child was is 5 or older, but there are no significant differences among mothers of small children.

Second, I assess the robustness of my results within subgroups (blacks versus non-blacks, Hispanics versus non-Hispanics, and parents with college degrees versus those without college degrees; results not shown). Most of the coefficients on black and Hispanic are imprecisely estimated, likely because of limited sample size; there were 119 black unemployed dads, 145 Hispanic unemployed dads, 86 black unemployed moms, and 286 Hispanic unemployed moms. However, the results may also suggest that the main model results pertain primarily to non-black, non-Hispanic, and non-college educated parents. Future research should explore this further.

Third, I examine whether results differ when unemployed and OOLF fathers are combined because OOLF fathers may be discouraged workers and thus have similar experiences to unemployed fathers (but no longer be looking for work). The results are largely consistent with the main analysis (results available on request). Including the OOLF fathers with the unemployed fathers increases the coefficients by a few minutes for total child care and educational/recreational child care (e.g., 38 minutes for total child care in the combined group vs. 35 minutes among only the unemployed).

Fourth, I examine whether controlling for the partner's usual work hours changes the results. I find the results are very similar. For total child care and routine child care the coefficients on unemployment are attenuated only slightly. The largest difference is for routine child care for fathers for which the coefficient on unemployment is reduced from 21.6 to 17.9 after accounting for partner's usual work hours. For fathers' educational/recreational child care time the coefficient is slightly larger after accounting for partner's usual work hours (14.23 vs. 11.98), but for mothers it remains almost identical to the main analyses. The weekday versus 
weekend pattern tested for H1B also held. Overall, the results are very consistent across models. Limitations

As with all studies there are limitations. The ATUS data are cross sectional, so one cannot examine transitions into and out of unemployment. This means that reverse causality is a (fairly unlikely) possibility_greater time spent in child care may lead to a job loss, rather than a job loss leading to greater time in child care. I also do not have data on the length of the unemployment spell, which could have consequences for time use; the division of labor is thought to be "sticky" (Gough and Killewald 2011), so it may be the case that the division of labor changes less than would be expected on the basis of lower economic resources during unemployment, but that as the length of a spell wears on, couples make additional changes. In addition, to provide a broad picture of the relationships it is necessary to combine time in specific child care tasks, thereby losing information in the data. A closer examination of specific tasks will be a useful endeavor for future research. Nonetheless, given the fairly limited literature on this specific topic and population, these estimates provide a useful starting point for future research on this topic.

A second drawback to the ATUS is that it is not possible to examine division of household labor from the perspective of the dyad, which is the basis for many of the household labor theories, because the ATUS collects time use data from only one person in the household. Being able to examine child care time from a dyadic perspective would provide a more complete picture of whether the results presented represent a reallocation of household labor between parents during unemployment or whether they represent changes in the amount of household production being completed. Previous research on housework indicates that both mechanisms may contribute to differences in time use during unemployment (Gough and Killewald 2011); it 
is possible this would also be true for child care. Lastly, I cannot uniquely distinguish between time- and resource-based theories because unemployment affects both time and resources, and both mechanisms may operate on time use; separating routine and educational/recreational child care helps to assess bargaining theory indirectly but not autonomy theory.

\section{Discussion}

A considerable amount of research has examined the relationship between paid labor and time in household labor, and some studies have examined how unemployment relates to time in housework, but study of the relationship between unemployment and time in child care for both mothers and fathers is limited in the United States. With this study I contribute to the literature by using data from the ATUS, testing existing theories of the division of household labor, and examining how unemployment is related to time in different types of child care.

Three theoretical perspectives undergird this study, as in other studies of housework and child care. The first theory is time availability and the related demand/response capacity approach. I generally find support for the time-based theories from an individual-level perspective; support for differences between weekdays and weekends is mixed. Unemployed parents spend more time on average in total child care, routine child care, and educational/recreational child care than employed parents, supporting H1A. These results are consistent with prior research on unemployment and housework, and studies of fathers as primary caregivers (Burda and Hamermesh 2010, Casper 1996, Gough and Killewald 2011).

In terms of differences related to weekdays versus weekend days (H1B), time constraint results are not supported. Unemployed fathers do spend more time in child care on weekdays than employed fathers, but they also spend considerably less time in child care on weekend days than employed fathers, with the magnitudes of the gaps cancelling each other out. This may indicate that unemployed fathers shift some of their child care responsibilities from weekends to 
weekdays during unemployment, while employed fathers may partially compensate for less time in child care on weekdays by spending more time in child care on weekends. For mothers the results are not consistent with H1B — the difference in gaps for weekdays versus weekends between unemployed and employed moms is not statistically significant. However, perhaps interestingly, both employed and unemployed mothers spend more time in child care on weekdays than on weekends. I discuss the rather striking gender difference in how unemployed fathers and mothers spend time in child care, compared to their employed counterparts, in more depth later in this section.

The second theoretical perspective was the resource perspective. To assess the possible role of resources in the bargaining context, given the lack of dyadic data, I tested the gaps in child care time between employed and unemployed parents to see if they were larger for routine versus educational/recreational child care (H2). I find some evidence for this hypothesis for fathers. The gap for fathers between unemployed and employed is larger for routine child care than for educational/recreational child care, but for mothers there is no significant difference in the gaps. Thus, there is some evidence consistent with bargaining predictions in the child care context for fathers when this indirect method of measurement is used.

Although both the time- and resource-based theories are conceived as gender neutral, there is abundant evidence in the literature that time in child care is gendered, as is time in housework. The third theoretical perspective, doing gender, predicts that if routine child care bears similarities to housework, the gaps in child care time between unemployed and employed mothers will be larger than those for fathers (H3A). This is not a certainty given the competing ideal father role. The gendered nature of child care also led me to hypothesize that the gaps between unemployed and employed fathers would be smaller for routine child care than for 
educational/recreational child care, because the latter is more desirable ( $\mathrm{H} 3 \mathrm{~B}$; opposite of $\mathrm{H} 2)$, and that the gaps between unemployed and employed mothers would be larger for routine child care versus educational/recreational child care because the former is more gender normative (H3C). I find very little support for these hypotheses. With regard to H3A, the gap between employed and unemployed mothers is only slightly larger than the gap between unemployed and employed fathers for total child care and is not statistically significant; the gap for routine child care is also not significant. For educational/recreational child care, the gap between employed and unemployed mothers is about 8 minutes larger than the gap between employed and unemployed fathers and statistically significant $(\mathrm{p}=0.04)$. Thus, for educational/recreational child care, there is minimal support for H3A. I find no support for H3B or H3C. For fathers the gap for routine child care is larger than the gap for educational/recreational child care, and for mothers the gap for educational/recreational child care is not significantly different than the gap for routine child care. The results are generally not consistent with a doing gender perspective in the way I hypothesized, though both results are potentially consistent with notions of intensive mothering and the ideal father norm.

While the evidence for doing gender tested in Hypotheses 3A-3C is minimal, the conception of doing gender tested here is rather specific. The more general idea that men and women perform gender in the household labor context is well supported by this analysis. Even though the gaps in child care time between unemployed and employed mothers are substantively very similar to the gaps in child care time between unemployed and employed fathers overall, mothers still spend much more time in child care than fathers, regardless of employment status. This is consistent with the notion of child care being normative for women and not men, and it is consistent with past research on time in housework. 
The analysis meant to tease out the role of time constraints by comparing weekdays to weekend days (Model 3) suggests that mothers and fathers have different approaches to time in child care when unemployed. Unemployed mothers spend more time in child care than their employed counterparts on weekdays, as do unemployed fathers, whether because they have more time available, to compensate for not contributing financially to the family, or for some other reason, such as pressure to engage in intensive parenting. However, unemployed fathers spend less time in child care on weekend days than their employed counterparts, which is not the case for mothers. One possible interpretation of this finding is that unemployed fathers are doing gender through shifting child care time around rather than simply increasing it (though they do end up spending more time in child care than employed counterparts over the course of an entire week). In other words, unemployed fathers may have the view that if they are going to be doing extra child care during the week (behavior that is non-normative for men) then they should compensate for this "deviant" behavior on the weekends by doing less child care than they normally would (and that employed fathers do). A second, more speculative, possibility is that mothers are playing a role in unemployed fathers' child care behavior. For example, if mothers perceive it as difficult to be home with the children all day (even if realistically many unemployed fathers are probably only caring for children after school), they may feel as though they need to reduce the burden on their partners by giving their partners a break from child care on the weekend. This is one reason why having dyadic data on time use is so useful; one could test whether partners of unemployed fathers are increasing their child care time on weekends at the same time that the fathers are decreasing time. Data on gender role attitudes could also help shed light on these potential explanations for the differing behavior of fathers and mothers.

The greater time in child care for unemployed parents compared to employed parents is 
not inconsequential in terms of social significance. Results can be contextualized in terms of weekly time use, financial implications, and possible benefits to children. In terms of the importance of these differences from a time perspective, using the coefficients from Model 3 to calculate the weekly difference in time (holding covariates constant), unemployed fathers spend about 2.25 more hours per week in child care than employed fathers. Comparing this to the average time in child care for employed fathers (5.8 hours, Table 1), this is $39 \%$ more hours. Unemployed fathers spend approximately $61 \%$ more time in routine care than employed fathers, and $21 \%$ more time in educational/recreational care. Mothers demonstrate a somewhat different pattern. Using the coefficients from Model 3 (holding covariates constant), unemployed mothers spend about 3.8 more hours per week in child care than employed mothers. Comparing this to the average time in child care for employed mothers ( 9.3 hours, Table 1 ), this is $41 \%$ more hours. Unemployed mothers spend approximately $34 \%$ more time in routine care per week compared to employed mothers and $46 \%$ more time in educational/recreational child care. Thus, whereas unemployed fathers are relatively more involved in routine care compared to employed fathers, the larger gap for mothers is with educational/recreational care.

In terms of financial implications, we can attempt to attach a dollar value to the extra hours of care each week using the average cost of a babysitter in urban areas. The average hourly rate is $\$ 10-15$ (care.com n.d.), so 2.25 extra hours of father care per week could potentially save a family $\$ 1125-\$ 1688$ over the course of a year (at $\$ 10-\$ 15 / \mathrm{hr}$ ). For mothers the savings could be as high as $\$ 1900-\$ 2850$ (at $\$ 10-\$ 15 / \mathrm{hr}$ ). Thus, especially for low-income families, greater hours of parent care among unemployed parents compared to employed parents could translate into significant savings.

Finally, we can think about potential benefits to children. Researchers have argued that 
greater parental education is important for child investments. Guryan and colleagues (2008) demonstrated that college-educated mothers spent about 6 more hours per week in child care than mothers with less than a high school education, and college-educated fathers spent about 4 more hours per week in child care compared to fathers with less than a high school education. Therefore, the extra 2.25 hours of child care per week that I calculate for unemployed fathers, and the extra 3.8 hours for unemployed mothers, are equivalent to more than half of the benefit of a college degree in terms of time investments. Given findings for educational differences in time investments for children's well-being, the extra time unemployed parents spend in child care compared to similar employed parents could benefit children's development, along with potentially helping to buffer the negative consequences of a loss of financial resources that may accompany job loss. There is one caveat: if unemployed parents are depressed, or providing a negative home environment, children may not experience benefits of additional parental child care. Studies that offer insight into parents' mental outlook during unemployment may help to shed light on this possibility.

In sum, I find considerable support for time-based theories at the individual level. But I find very limited support for bargaining theory. I also find limited support for doing gender in terms of the hypotheses tested, but, as noted above, there is strong evidence of doing gender in the broader sense of the theory. While the time-based results may seem self evident, the lack of evidence for bargaining and for doing gender in terms of types of tasks suggests there may be something qualitatively different about the division of child care in a household compared to the division of housework, a position also argued by Sullivan (2013). The broader evidence for doing gender suggests that, similar to other types of labor, and despite fathers' endorsement of the ideal father norm, gendered norms and expectations may remain influential in the decisions 
parents make about caring for children.

Although two of the three main theoretical approaches to the study of the division of household labor appear mostly applicable in the child care context, researchers ought to consider the development of new, multi-faceted theories of the relationship between paid work and child care. For example, one might build from the demand/response capacity model to incorporate cultural notions of good parenting, expectations for caring, expectations of the provider role, gender dynamics within households, and so forth. Richer theoretical explanations, together with additional sources of data, may help us better understand the underlying dynamics of gendered child care arrangements in the home whether during employment or unemployment.

To develop and refine theories of the division of child care time, researchers also need the ability to analyze more sources of data. The ATUS is valuable for its fine-grained measures of child care time, but longitudinal data would shed additional light on how families make child care decisions. Researchers designing new longitudinal surveys, or modifying existing surveys, should consider the benefits of including measures of time in child care to allow researchers the option of studying changes in child care time like they have done for changes in housework time. Although longitudinal time diary data would be ideal, this type of data collection is currently cost prohibitive. Thus, researchers should develop a battery of validated, stylized questions (similar to those asked about housework) so that more data can be collected on this important topic. 


\section{References}

Berk, Sarah F. 1985. The Gender Factory: The Apportionment of Work in American Households. New York: Plenum Press.

Bianchi, Suzanne M. 2000. "Maternal Employment and Time with Children:

Dramatic Change Or Surprising Continuity?” Demography 37: 4:401-414.

Bianchi, Suzanne M., Melissa A. Milkie, Liana C. Sayer and John P. Robinson. 2000. “Is Anyone Doing the Housework? Trends in the Gender Division of Household Labor." Social Forces 79: 1:191-228.

Bittman, Michael, Lyn Craig and Nancy Folbre. 2004. "Packaging Care." Family Time: The Social Organization of Care 2:133.

Bittman, Michael, Paula England, Liana Sayer, Nancy Folbre and George Matheson. 2003. "When does Gender Trump Money? Bargaining and Time in Household Work." American Journal of Sociology 109: 1:186-214.

Blau, David M. 2001. The Child Care Problem: An Economic Analysis. New York: Russell Sage Foundation.

Brayfield, April. 1995. "Juggling Jobs and Kids: The Impact of Employment Schedules on Fathers' Caring for Children." Journal of Marriage and the Family 57:321-332.

Brines, Julie. 1994. "Economic Dependency, Gender, and the Division of Labor at Home." American Journal of Sociology 100: 3:652-688.

Burda, Michael C., and Daniel S. Hamermesh. 2010. "Unemployment, Market Work and Household Production.” Economics Letters 107: 2:131-133.

Care.com. (n.d.) How Much Should You Pay Your Sitter? Retrieved from https://www.care.com/c/stories/3158/how-much-should-you-pay-your-sitter/ Casper, Lynne. M. 1996. Who's Minding Our Preschoolers? U.S. Census Bureau. 
(files.eric.ed.gov/fulltext/ED395670.pdf). Last accessed June 29, 2015.

Chesley, Noelle, and Sarah Flood. 2017. "Signs of Change? At-Home and Breadwinner Parents' Housework and Child-Care Time." Journal of Marriage and Family 79: 2:511-534.

Coltrane, Scott. 1996. Family Man. New York: Oxford University Press.

Connelly, Rachel, and Jean Kimmel. 2010. The Time use of Mothers in the United States at the Beginning of the 21st Century. WE Upjohn Institute.

Coverman, Shelley. 1985. "Explaining Husbands' Participation in Domestic Labor." The Sociological Quarterly 26: 1:81-97.

Craig, Lyn, and Killian Mullan. 2010. "Parenthood, Gender and Work-family Time in the United States, Australia, Italy, France, and Denmark.” Journal of Marriage and Family 72: 5:1344-1361.

England, Paula, and George Farkas. 1986. Households, Employment, and Gender: A Social, Economic and Demographic View. Hawthorne, NY: Aldine.

Gerson, Kathleen. 1993. No Man's Land: Men's Changing Commitments to Family and Work. New York: Basic Books.

-----. 2010. The Unfinished Revolution: How a New Generation is Reshaping Family, Work, and Gender in America. New York: Oxford University Press.

Goldscheider, Frances K., and Linda J. Waite. 1991. New Families, No Families? The Transformation of the American Home. Berkeley, CA: University of California Press. Gough, Margaret, and Alexandra Killewald. 2011. "Unemployment in Families: The Case of Housework." Journal of Marriage and Family 73:1085-1100.

Gupta, Sanjiv. 2006. "Her Money, Her Time: Women’s Earnings and their Housework Hours." Social Science Research 35: 4:975-999. 
-----. 2007. “Autonomy, Dependence, Or Display? The Relationship between Married Women's Earnings and Housework." Journal of Marriage and Family 69: 2:399-417.

Guryan, Jonathan, Erik Hurst and Melissa Kearney. 2008. "Parental Education and Parental Time with Children." The Journal of Economic Perspectives 22: 3:23.

Hays, Sharon. 1998. The Cultural Contradictions of Motherhood. New Haven, CT: Yale University Press.

Hochschild, Arlie, and Anne Machung. 1989. The Second Shift: Working Parents and the Revolution at Home. New York: Viking.

Hofferth, Sandra L., Sarah M. Flood, and Matthew Sobek. 2013. American Time Use Survey Data Extract System: Version 2.4 [Dataset]. Maryland Population Research Center, University of Maryland, College Park, MD, and Minnesota Population Center, University of Minnesota, Minneapolis, MN. (http://www.atusdata.org).

Hook, Jennifer L., and Christina M. Wolfe. 2012. “New Fathers? Residential Fathers' Time with Children in Four Countries." Journal of Family Issues 33: 4:415-450.

Killewald, Alexandra, and Margaret Gough. 2010. “Money Isn't Everything: Wives' Earnings and Housework Time.” Social Science Research 39: 6:987-1003.

Krueger, Alan B., Daniel Kahneman, David Schkade, Norbert Schwarz and Arthur A. Stone. 2009. "National time accounting: The currency of life." Pp. 9-86 in Measuring the subjective well-being of nations: National accounts of time use and well-being. Chicago: University of Chicago Press.

Raley, Sara, Suzanne M. Bianchi and Wendy Wang. 2012. "When do Fathers Care? Mothers' Economic Contribution and Fathers' Involvement in Child Care." American Journal of Sociology 117: 5: 1422-1459. 
Robinson, John, and Geoffrey Godbey. 1999. Time for life. University Park, PA: Pennsylvania State University Press.

Roeters, Anne, Tanja Van Der Lippe and Esther S. Kluwer. 2009. "Parental Work Demands and the Frequency of Child-Related Routine and Interactive Activities." Journal of Marriage and Family 71: 5:1193-1204.

Sayer, Liana C., Suzanne M. Bianchi and John P. Robinson. 2004. "Are Parents Investing Less in Children? Trends in Mothers' and Fathers' Time with Children.” American Journal of Sociology 110: 1:1-43.

Shamir, Boas. 1986. “Unemployment and Household Division of Labor.” Journal of Marriage and the Family 48:195-206.

Ström, Sara. 2002. "Unemployment and Gendered Divisions of Domestic Labor.” Acta Sociologica, 45:89-106.

Sullivan, Oriel. 2013. "What do we Learn about Gender by Analyzing Housework Separately from Child Care? Some Considerations from Time-use Evidence.” Journal of Family Theory \& Review 5: 2:72-84.

Sullivan, Oriel, and Jonathan Gershuny. 2013. "Domestic Outsourcing and Multitasking: How Much do They Really Contribute?” Social Science Research 42: 5:1311-1324.

West, Candace, and Don H. Zimmerman. 1987. "Doing Gender.” Gender \& Society, 1:125-151. Yeung, W. Jean, John F. Sandberg, Pamela E. Davis-Kean and Sandra L. Hofferth. 2001. “Children's Time with Fathers in Intact Families." Journal of Marriage and Family 63: 1:136-154. 
Table 1. Descriptive Statistics ${ }^{\mathrm{a}}$

\begin{tabular}{|c|c|c|c|c|c|c|c|}
\hline & \multicolumn{3}{|c|}{ Fathers } & \multicolumn{4}{|c|}{ Mothers } \\
\hline & Employed & Unemp. & $\underline{\text { OOLF }}$ & Employed & Unemp. & OOLF & \\
\hline & $\frac{\text { Mean }}{(\mathrm{SDR} S E)}$ & (SDR SE) & $\stackrel{\text { Mean }}{(\mathrm{SDR} S E)}$ & $\frac{\text { Mean }}{(\mathrm{SDR} S E)}$ & $\stackrel{\text { Mean }}{(\mathrm{SDR} S E)}$ & $\stackrel{\text { Mean }}{\text { (SDR SE) }}$ & $\underline{\text { Range }}$ \\
\hline $\begin{array}{l}\text { Age at last CPS } \\
\text { interview }\end{array}$ & $39.64(0.08)$ & $\begin{array}{l}38.34 \\
(0.42)\end{array}$ & $\begin{array}{l}39.65 \\
(0.66)\end{array}$ & $\begin{array}{l}38.26 \\
(0.08)\end{array}$ & $\begin{array}{l}35.43 \\
(0.40)\end{array}$ & $\begin{array}{l}35.40 \\
(0.14)\end{array}$ & $18-65$ \\
\hline Race/Ethnicity & & & & & & & \\
\hline White & .67 & .49 & .56 & .71 & .51 & .59 & $0-1$ \\
\hline Black & .07 & .20 & .13 & .08 & .09 & .04 & $0-1$ \\
\hline Hispanic & .20 & .23 & .24 & .15 & 34 & .29 & \\
\hline American & .01 & .02 & .01 & .01 & .02 & .01 & $0-1$ \\
\hline $\begin{array}{l}\text { Indian/Alaskan } \\
\text { Native }\end{array}$ & & & & & & & \\
\hline $\begin{array}{l}\text { Asian/Pacific } \\
\text { Islander }\end{array}$ & .05 & .05 & .06 & .05 & .04 & .06 & $0-1$ \\
\hline Multiracial & .01 & .01 & .01 & .01 & .01 & .01 & $0-1$ \\
\hline Education & & & & & & & \\
\hline $\begin{array}{l}\text { Less than high } \\
\text { school }\end{array}$ & .15 & .27 & .24 & .09 & .28 & .22 & $0-1$ \\
\hline High school & .26 & .34 & .28 & .23 & .28 & .26 & $0-1$ \\
\hline Some college & .24 & .21 & .23 & .28 & .24 & .23 & $0-1$ \\
\hline College degree & .35 & .18 & .24 & .40 & .20 & .30 & $0-1$ \\
\hline Children & & & & & & & \\
\hline Two children & .64 & .60 & .60 & .59 & .62 & .71 & $0-1$ \\
\hline $\begin{array}{l}\text { Three or more } \\
\text { children }\end{array}$ & .23 & .24 & .23 & .19 & .27 & .33 & $0-1$ \\
\hline Age of youngest child & $6.33(0.04)$ & $6.20(0.24)$ & $6.37(0.31)$ & $6.97(0.05)$ & $5.68(0.20)$ & $4.83(0.07)$ & $0-17$ \\
\hline Child less than age 5 & .46 & .47 & .47 & .40 & .49 & .59 & $0-1$ \\
\hline Region & & & & & & & \\
\hline Northeast & .18 & .18 & .18 & .18 & .16 & .15 & $0-1$ \\
\hline Midwest & .24 & .25 & .22 & .25 & .22 & .19 & $0-1$ \\
\hline South & .34 & .31 & .34 & .35 & .34 & .36 & $0-1$ \\
\hline West & .24 & .26 & .25 & .22 & .29 & .29 & $0-1$ \\
\hline Metropolitan & .83 & .84 & .82 & .82 & .83 & .85 & $0-1$ \\
\hline Weekend time diary & .28 & .28 & .33 & .29 & .29 & .28 & $0-1$ \\
\hline $\begin{array}{l}\text { Spouse/partner } \\
\text { employed at ATUS } \\
\text { interview }\end{array}$ & .64 & .65 & .65 & .90 & .81 & .92 & $0-1$ \\
\hline $\begin{array}{l}\text { State-level } \\
\text { unemployment rate } \\
\text { Time use } \\
\text { (minutes/day) }\end{array}$ & $6.73(0.02)$ & $7.62(0.10)$ & $7.17(0.16)$ & $6.70(0.02)$ & $7.39(0.09)$ & $6.79(0.04)$ & $2.5-13.8$ \\
\hline Total child care & $49.43(0.67)$ & $\begin{array}{l}79.68 \\
(4.42)\end{array}$ & $\begin{array}{l}90.28 \\
(6.25)\end{array}$ & $\begin{array}{l}82.55 \\
(0.92)\end{array}$ & $\begin{array}{l}116.25 \\
(4.37)\end{array}$ & $\begin{array}{l}152.50 \\
(2.11)\end{array}$ & $0-476$ \\
\hline Routine child care & $21.77(0.37)$ & $\begin{array}{l}41.25 \\
(2.92)\end{array}$ & $\begin{array}{l}44.62 \\
(3.84)\end{array}$ & $\begin{array}{l}47.13 \\
(0.63)\end{array}$ & $\begin{array}{l}65.45 \\
(3.01)\end{array}$ & $\begin{array}{l}83.57 \\
(1.46)\end{array}$ & $0-320$ \\
\hline $\begin{array}{l}\text { Educational/recreati } \\
\text { onal child care }\end{array}$ & $26.78(0.44)$ & $\begin{array}{l}36.39 \\
(2.58)\end{array}$ & $\begin{array}{l}43.05 \\
(4.14)\end{array}$ & $\begin{array}{l}34.31 \\
(0.49)\end{array}$ & $\begin{array}{l}49.75 \\
(2.64)\end{array}$ & $\begin{array}{l}67.04 \\
(1.30)\end{array}$ & $0-330$ \\
\hline$N$ & 19402 & 753 & 509 & 16160 & 1042 & 6332 & \\
\hline
\end{tabular}

${ }^{a}$ Descriptive statistics are estimated using the replicate weights provided in the ATUS. For continuous variables, the successive difference replication (SDR) standard errors are reported. For proportions, standard errors are not provided because the entire distribution is shown. 
Table 2. Estimates of Association Between Unemployment and Time (minutes/day) in Total Child Care, Routine Child Care, and Educational/recreational Child Care for Cohabiting and Married Parents

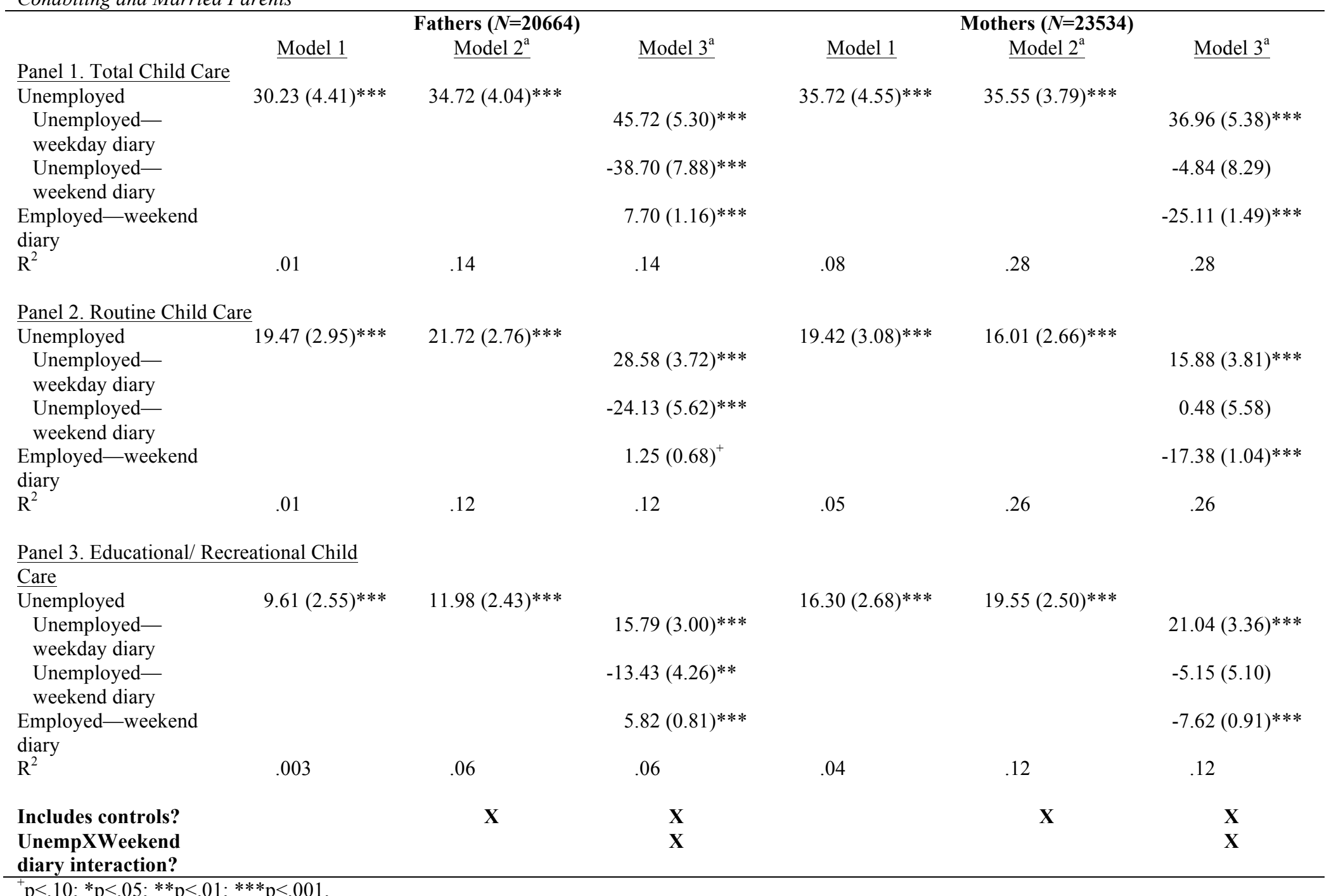

${ }^{a}$ Models 2 and 3 include the following control variables: out of the labor force, spouse employment, marital status, state-level unemployment rate, number of children, age of the youngest child, region, metro status, age at the CPS interview, education, race/ethnicity, and weekend indicator. 
Table 3. Estimates of Association Between Unemployment and Time (minutes/day) in Total Child Care, Routine Ch Care, and Educational/recreational Child Care for Cohabiting and Married Parents, by Child Age

\begin{tabular}{|c|c|c|c|c|}
\hline \multirow{3}{*}{ Panel 1. Total Time in Child Car } & \multicolumn{2}{|c|}{ Fathers $(N=20664)$} & \multicolumn{2}{|c|}{ Mothers $(N=\mathbf{2 3 5 3 4})$} \\
\hline & Model $2^{\mathrm{a}}$ & ${\text { Model } 3^{\mathrm{a}}}$ & Model $2^{\mathrm{a}}$ & Mode \\
\hline & & & & \\
\hline Unemployed, child less than 5 & $22.75(9.73)^{*}$ & & $4.49(8.44)$ & \\
\hline Unemployed, child 5 or older & $24.10(4.71)^{* * *}$ & & $33.65(4.92)^{* * *}$ & \\
\hline Employed, child less than 5 & $7.86(2.37)^{* *}$ & & $14.17(2.66)^{* * *}$ & \\
\hline \multicolumn{5}{|l|}{ Weekday diary, child 5 or older } \\
\hline Unemployed & & $27.85(5.69)^{* * *}$ & & $38.21(6$. \\
\hline \multicolumn{5}{|l|}{ Weekday diary, child less than 5} \\
\hline Unemployed & & $39.40(13.38)^{* *}$ & & $-1.78(1]$ \\
\hline Employed & & $3.50(2.59)$ & & $16.11(2$. \\
\hline \multicolumn{5}{|l|}{ Weekend diary, child 5 or older } \\
\hline Unemployed & & $-14.48(8.96)$ & & $-16.58(9$. \\
\hline Employed & & $0.66(1.26)$ & & $-22.08(1$ \\
\hline \multicolumn{5}{|l|}{ Weekend diary, child less than 5} \\
\hline Unemployed & & $-53.06(17.43)^{* * *}$ & & $22.46(1<$ \\
\hline Employed & & $15.33(2.62)^{* * *}$ & & $-6.72(2$. \\
\hline $\mathrm{R}^{2}$ & .14 & .14 & .28 & .28 \\
\hline \multicolumn{5}{|l|}{ Panel 2. Routine Child Care } \\
\hline 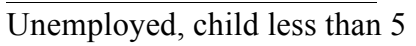 & $15.77(6.35)^{*}$ & & $-0.86(5.97)$ & \\
\hline Unemployed, child 5 or older & $14.36(2.80)^{* * *}$ & & $16.64(3.26)^{* * *}$ & \\
\hline Employed, child less than 5 & $5.71(1.17)^{* * *}$ & & $11.21(1.85)^{* * *}$ & \\
\hline \multicolumn{5}{|l|}{ Weekday diary, child 5 or older } \\
\hline Unemployed & & $16.44(3.46)^{* * *}$ & & $18.94(4$. \\
\hline \multicolumn{5}{|l|}{ Weekday diary, child less than 5} \\
\hline Unemployed & & $26.79(8.92)^{* *}$ & & $-5.82(7$ \\
\hline Employed & & $4.02(1.34)^{* *}$ & & $13.01(2$. \\
\hline \multicolumn{5}{|l|}{ Weekend diary, child 5 or older } \\
\hline Unemployed & & $-7.93(5.64)$ & & $-8.30(5$ \\
\hline Employed & & $-1.52(0.60)^{*}$ & & $-14.53(1$. \\
\hline \multicolumn{5}{|l|}{ Weekend diary, child less than 5} \\
\hline Unemployed & & $-35.33(12.46)^{* *}$ & & $17.23(9$. \\
\hline Employed & & $6.04(1.58)^{* * *}$ & & $-6.32(1$. \\
\hline $\mathrm{R}^{2}$ & .13 & .13 & .26 & .26 \\
\hline \multicolumn{5}{|c|}{ Panel 3. Educational/ Recreational Child Care } \\
\hline Unemployed, child less than 5 & $4.81(5.77)$ & & $5.14(5.69)$ & \\
\hline Unemployed, child 5 or older & $9.73(2.82)^{* *}$ & & $17.10(3.57)^{* * *}$ & \\
\hline Employed, child less than 5 & $1.84(1.51)$ & & $2.07(1.77)$ & \\
\hline \multicolumn{5}{|l|}{ Weekday diary, child 5 or older } \\
\hline Unemployed & & $11.87(3.52)^{* *}$ & & $19.67(4$. \\
\hline \multicolumn{5}{|l|}{ Weekday diary, child less than 5} \\
\hline Unemployed & & $8.65(7.50)$ & & $3.07(7$. \\
\hline Employed & & $-0.73(1.63)$ & & $2.17(1$. \\
\hline \multicolumn{5}{|l|}{ Weekend diary, child 5 or older } \\
\hline Unemployed & & $-8.27(5.30)$ & & $-9.40(6$. \\
\hline Employed & & $1.72(0.93)^{+}$ & & $-7.51(0$. \\
\hline \multicolumn{5}{|l|}{ Weekend diary, child less than 5} \\
\hline Unemployed & & $-11.65(10.22)$ & & $7.80(10$ \\
\hline Employed & & $8.91(1.77)^{* * *}$ & & $-0.27(1$. \\
\hline $\mathrm{R}^{2}$ & .06 & .06 & .12 & .12 \\
\hline Includes controls? & $\mathbf{X}$ & $\mathbf{X}$ & $\mathbf{X}$ & $\mathbf{X}$ \\
\hline $\begin{array}{l}\text { UnempXWeekend diary } \\
\text { interaction? }\end{array}$ & & $\mathbf{X}$ & & $\mathbf{X}$ \\
\hline
\end{tabular}


${ }^{a}$ Models 2 and 3 include the following control variables: out of the labor force, spouse employment, marital status, statelevel unemployment rate, number of children, age of the youngest child, region, metro status, age at the CPS interview, education, race/ethnicity 


\section{Appendix A}

Table A1. Components of Total Time in Child Care Measure by Routine and Educational/Recreational

\begin{tabular}{|c|c|}
\hline \multicolumn{2}{|c|}{ Total Time in Child Care Tasks } \\
\hline Routine Child Care Tasks & Educational/Recreational Child Care Tasks \\
\hline Physical care of household children & Playing with household children \\
\hline Looking after household children as primary activity & Playing sports with household children \\
\hline Waiting for/with household children & Helping/teaching household children \\
\hline Caring/helping household children NEC* & Homework with household children \\
\hline Providing medical care to household children & Waiting associated with household child's education \\
\hline Waiting associated with household child's health & Reading to/with household children \\
\hline Organizing/planning for household children & Arts/crafts with household children \\
\hline Picking up/dropping off household children & Talking/listening to household children \\
\hline Obtaining medical care for household child & Attending household children's events \\
\hline Related to household child's health NEC* & Meetings/school conferences for household children \\
\hline & Home schooling household children \\
\hline & Related to household children's education NEC* \\
\hline
\end{tabular}

*Not elsewhere classified 
Table A2. Complete Results of Estimates of Association between Unemployment and Time (minutes/day) in Total Child Care for Cohabiting and Married Parents

\begin{tabular}{|c|c|c|c|c|}
\hline \multirow[b]{3}{*}{ Unemployed } & \multicolumn{2}{|c|}{ Fathers } & \multicolumn{2}{|c|}{ Mothers } \\
\hline & Model 2 & Model 3 & Model 2 & Model 3 \\
\hline & $34 . \overline{72(4.04) * * *}$ & & $35 . \overline{55(3.79) * * *}$ & \\
\hline $\begin{array}{l}\text { Unemployed- } \\
\text { weekend diary }\end{array}$ & & $-38.70(7.88)^{* * *}$ & & $-4.84(8.29)$ \\
\hline $\begin{array}{l}\text { Unemployed- } \\
\text { weekday diary }\end{array}$ & & $45.72(5.31)^{* * *}$ & & $36.96(5.38)^{* * *}$ \\
\hline $\begin{array}{l}\text { Weekend } \\
\text { Employed- } \\
\text { weekend diary }\end{array}$ & $6.08(1.17)^{* * *}$ & $7.70(1.16)^{* * *}$ & $-25.35(1.44)^{* * *}$ & $-25.11(1.49)^{* * *}$ \\
\hline $\begin{array}{l}\text { Out of the labor } \\
\text { force }\end{array}$ & $44.46(5.67)^{* * *}$ & $44.39(5.67)^{* * *}$ & $56.06(2.04)^{* * *}$ & $56.06(2.04)^{* * *}$ \\
\hline $\begin{array}{l}\text { Spouse/partner } \\
\text { employed }\end{array}$ & $8.60(1.39)^{* * *}$ & $8.59(1.39)^{* * *}$ & $11.95(2.43)^{* * *}$ & $11.96(2.43)^{* * *}$ \\
\hline $\begin{array}{l}\text { State-level } \\
\text { unemployment rate }\end{array}$ & $0.81(0.31)^{*}$ & $0.81(0.31)^{*}$ & $0.33(0.36)$ & $0.33(0.36)$ \\
\hline \multicolumn{5}{|l|}{ Children } \\
\hline 2 & $6.43(1.46)^{* * *}$ & $6.45(1.46)^{* * *}$ & $9.66(1.58)^{* * *}$ & $9.67(1.58)^{* * *}$ \\
\hline $3+$ & $3.67(1.98)^{+}$ & $3.70(1.98)^{+}$ & $9.45(2.50)^{* * *}$ & $9.45(2.51)^{* * *}$ \\
\hline Age youngest child & $-4.75(0.15)^{* * *}$ & $-4.76(0.15)^{* * *}$ & $-7.83(0.21)^{* * *}$ & $-7.83(0.21)^{* * *}$ \\
\hline \multicolumn{5}{|l|}{$\begin{array}{l}\text { Region (Northeast is } \\
\text { omitted) }\end{array}$} \\
\hline Midwest & $-4.27(1.86)^{*}$ & $-4.34(1.86)^{*}$ & $-7.79(2.63)^{* *}$ & $-7.80(2.63)^{* *}$ \\
\hline South & $-9.39(1.84)^{* * *}$ & $-9.32(1.84)^{* * *}$ & $-9.07(2.41)^{* * *}$ & $-9.07(2.41)^{* * *}$ \\
\hline West & $-8.38(2.12)^{* * *}$ & $-8.40(2.11)^{* * *}$ & $-14.40(2.59)^{* * *}$ & $-14.40(2.59)^{* * *}$ \\
\hline Metropolitan & $8.34(1.47)^{* * *}$ & $8.25(1.47)^{* * *}$ & $8.80(2.03)^{* * *}$ & $8.80(2.03)^{* * *}$ \\
\hline $\begin{array}{l}\text { Age at CPS } \\
\text { interview }\end{array}$ & $-0.41(0.10)^{* * *}$ & $-0.41(0.10)^{* * *}$ & $-0.80(0.15)^{* * *}$ & $-0.80(0.15)^{* * *}$ \\
\hline \multicolumn{5}{|l|}{$\begin{array}{l}\text { Education (Less } \\
\text { than high school is } \\
\text { omitted) }\end{array}$} \\
\hline $\begin{array}{l}\text { High school } \\
\text { diploma }\end{array}$ & $1.95(2.46)$ & $1.89(2.43)$ & $11.30(3.46)^{* *}$ & $11.29(3.46)^{* *}$ \\
\hline Some college & $11.18(2.73)^{* * *}$ & $11.21(2.70)^{* * *}$ & $17.11(2.76)^{* * *}$ & $17.11(2.76)^{* * *}$ \\
\hline College degree & $19.79(2.49)^{* * *}$ & $19.75(2.46)^{* * *}$ & $37.14(3.03)^{* * *}$ & $37.13(3.03)^{* * *}$ \\
\hline \multicolumn{5}{|l|}{$\begin{array}{l}\text { Race (White is } \\
\text { omitted) }\end{array}$} \\
\hline Black & $-16.48(2.46)^{* * *}$ & $-16.63(2.48)^{* * *}$ & $-30.44(3.12)^{* * *}$ & $-30.42(3.13)^{* * *}$ \\
\hline Hispanic & $-14.84(2.28)^{* * *}$ & $-14.72(2.26)^{* * *}$ & $-28.69(2.48)^{* * *}$ & $-28.71(2.48)^{* * *}$ \\
\hline $\begin{array}{l}\text { American Indian/ } \\
\text { Alaskan Native }\end{array}$ & $-13.14(8.35)$ & $-13.30(8.35)$ & $-31.57(12.52)^{*}$ & $-31.71(12.52)^{*}$ \\
\hline $\begin{array}{l}\text { Asian/ Hawaiian } \\
\text { Pacific Islander }\end{array}$ & $-3.20(3.34)$ & $-3.03(3.33)$ & $-5.37(3.83)$ & $-5.36(3.83)$ \\
\hline Multiracial & $-5.11(5.82)$ & $-4.74(5.78)$ & $-0.81(7.30)$ & $-0.81(7.30)$ \\
\hline Constant & $72.32(5.27)^{* * *}$ & $71.74(5.23)^{* * *}$ & $140.30(6.86)^{* * *}$ & $140.23(6.86)^{* * *}$ \\
\hline $\mathrm{R}^{2}$ & .14 & .14 & .28 & .28 \\
\hline$N$ & 20664 & 20664 & 23534 & 23534 \\
\hline
\end{tabular}


Table A3. Complete Results of Estimates of Association between Unemployment and Time (minutes/day) in Routine Child Care for Cohabiting and Married Parents

\begin{tabular}{|c|c|c|c|c|}
\hline \multirow[b]{3}{*}{ Unemployed } & \multicolumn{2}{|c|}{$\begin{array}{l}\text { Fathers } \\
\end{array}$} & \multicolumn{2}{|c|}{ Mothers } \\
\hline & Model 2 & Model 3 & Model 2 & Model 3 \\
\hline & $21 . \overline{72(2.76) * * *}$ & & $16 . \overline{01(2.66)^{* * *}}$ & \\
\hline $\begin{array}{l}\text { Unemployed- } \\
\text { weekend diary }\end{array}$ & & $-24.13(5.62)^{* * *}$ & & $0.47(5.58)$ \\
\hline $\begin{array}{l}\text { Unemployed- } \\
\text { weekday diary }\end{array}$ & & $28.58(3.72)^{* * *}$ & & $15.88(3.81)^{* * *}$ \\
\hline $\begin{array}{l}\text { Weekend } \\
\text { Employed- } \\
\text { weekend diary }\end{array}$ & $0.24(0.69)$ & $1.25(0.68)^{+}$ & $-17.36(1.06)^{* * *}$ & $-17.38(1.04)^{* * *}$ \\
\hline $\begin{array}{l}\text { Out of the labor } \\
\text { force }\end{array}$ & $24.76(3.65)^{* * *}$ & $24.71(3.65)^{* * *}$ & $24.98(1.42)^{* * *}$ & $24.98(1.42)^{* * *}$ \\
\hline $\begin{array}{l}\text { Spouse/partner } \\
\text { employed }\end{array}$ & $6.10(0.81)^{* * *}$ & $6.09(0.81)^{* * *}$ & $7.11(1.86)^{* * *}$ & $7.10(1.86)^{* * *}$ \\
\hline $\begin{array}{l}\text { State-level } \\
\text { unemployment rate }\end{array}$ & $0.15(0.20)$ & $0.15(0.20)$ & $-0.11(0.25)$ & $-0.11(0.25)$ \\
\hline \multicolumn{5}{|l|}{ Children } \\
\hline 2 & $3.61(0.83)^{* * *}$ & $3.62(0.83) * * *$ & $7.50(1.06)^{* * *}$ & $7.50(1.06)^{* * *}$ \\
\hline $3+$ & $1.88(1.10)^{+}$ & $1.90(1.10)^{+}$ & $8.20(1.62)^{* * *}$ & $8.20(1.57)^{* * *}$ \\
\hline Age youngest child & $-2.46(0.08)^{* * *}$ & $-2.47(0.08)^{* * *}$ & $-4.92(0.14)^{* * *}$ & $-4.92(0.14)^{* * *}$ \\
\hline \multicolumn{5}{|l|}{$\begin{array}{l}\text { Region (Northeast is } \\
\text { omitted) }\end{array}$} \\
\hline Midwest & $-3.90(1.19)^{* *}$ & $-3.94(1.19)^{* *}$ & $-4.06(1.70)^{*}$ & $-4.06(1.39)^{* *}$ \\
\hline South & $-5.24(1.19)^{* * *}$ & $-5.21(1.18)^{* * *}$ & $-3.98(1.62)^{*}$ & $-3.98(1.62)^{*}$ \\
\hline West & $-4.50(1.22)^{* * *}$ & $-4.51(1.22)^{* * *}$ & $-7.25(1.78)^{* * *}$ & $-7.25(1.78)^{* * *}$ \\
\hline Metropolitan & $3.95(0.88) * * *$ & $3.89(0.88)^{* * *}$ & $4.08(1.39)^{* *}$ & $4.07(1.39)^{* *}$ \\
\hline $\begin{array}{l}\text { Age at CPS } \\
\text { interview }\end{array}$ & $-0.23(0.05)^{* * *}$ & $-0.23(0.05)^{* * *}$ & $-0.71(0.10)^{* * *}$ & $-0.71(0.10)^{* * *}$ \\
\hline \multicolumn{5}{|l|}{$\begin{array}{l}\text { Education (Less } \\
\text { than high school is } \\
\text { omitted) }\end{array}$} \\
\hline $\begin{array}{l}\text { High school } \\
\text { diploma }\end{array}$ & $0.13(1.34)$ & $0.09(1.33)$ & $6.45(2.28)^{* *}$ & $6.45(2.28)^{* *}$ \\
\hline Some college & $4.82(1.51)^{* *}$ & $4.84(1.50)^{* *}$ & $8.28(1.99)^{* * *}$ & $8.28(1.99)^{* * *}$ \\
\hline College degree & $8.74(1.44)^{* * *}$ & $8.71(1.43)^{* * *}$ & $18.27(2.02)^{* * *}$ & $18.27(2.02)^{* * *}$ \\
\hline \multicolumn{5}{|l|}{$\begin{array}{l}\text { Race (White is } \\
\text { omitted) }\end{array}$} \\
\hline Black & $-7.67(1.42)^{* * *}$ & $-7.76(1.43)^{* * *}$ & $-10.87(2.03)^{* * *}$ & $-10.87(2.04)^{* * *}$ \\
\hline Hispanic & $-8.28(1.30)^{* * *}$ & $-8.20(1.29)^{* * *}$ & $-10.25(1.69)^{* * *}$ & $-10.25(1.69)^{* * *}$ \\
\hline $\begin{array}{l}\text { American Indian/ } \\
\text { Alaskan Native }\end{array}$ & $-7.64(5.12)$ & $-7.74(5.15)$ & $-13.36(7.32)^{+}$ & $-13.34(7.34)^{+}$ \\
\hline $\begin{array}{l}\text { Asian/ Hawaiian } \\
\text { Pacific Islander }\end{array}$ & $-3.20(2.28)$ & $-3.09(2.26)$ & $-1.88(2.62)$ & $-1.88(2.62)$ \\
\hline Multiracial & $-2.38(3.17)$ & $-2.15(3.14)$ & $5.78(5.07)$ & $5.78(5.07)$ \\
\hline Constant & $37.53(2.90)^{* * *}$ & $37.17(2.88)^{* * *}$ & $93.43(4.79)^{* * *}$ & $93.44(4.78)^{* * *}$ \\
\hline $\mathrm{R}^{2}$ & .12 & .12 & .26 & .26 \\
\hline$N$ & 20664 & 20664 & 23534 & 23534 \\
\hline
\end{tabular}


Table A4. Complete Results of Estimates of Association between Unemployment and Time (minutes/day) in Educational/Recreational Child Care for Cohabiting and Married Parents

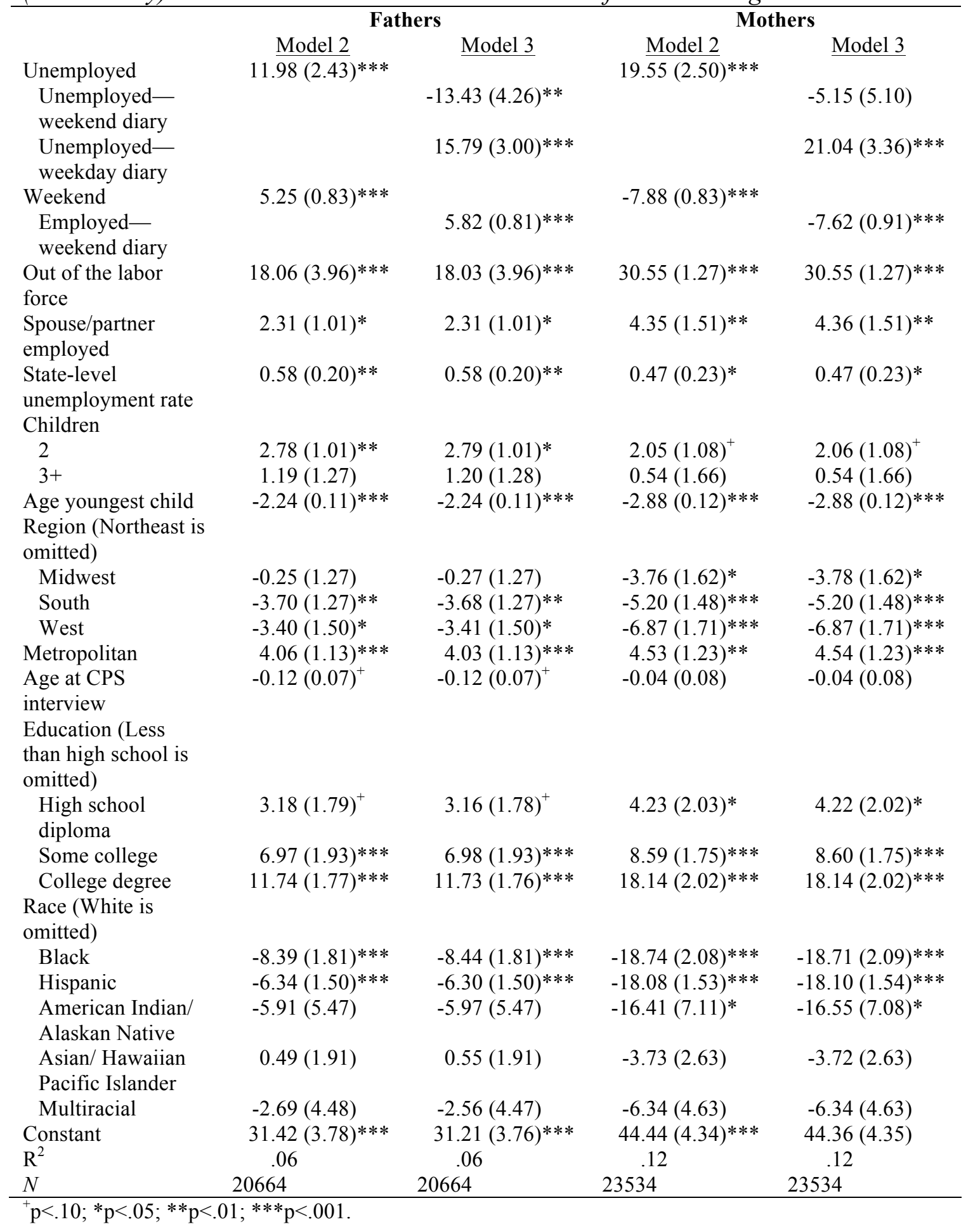

